Revue bibliographique pour le domaine irano-aryen

\title{
The Reflective Heart - Discovering Spiritual Intelligence in Ibn 'Arabî's Meccan Illuminations. Louisville, Fons Vitae, 2005, 420 p.
}

\section{Pierre Lory}

\section{(2) OpenEdition}

Journals

Édition électronique

URL : http://journals.openedition.org/abstractairanica/12582

DOI : 10.4000/abstractairanica. 12582

ISSN : 1961-960X

Éditeur :

CNRS (UMR 7528 Mondes iraniens et indiens), Éditions de l'IFRI

\section{Édition imprimée}

Date de publication : 15 mai 2007

ISSN : 0240-8910

Référence électronique

Pierre Lory, « The Reflective Heart - Discovering Spiritual Intelligence in Ibn 'Arabî's Meccan

Illuminations. Louisville, Fons Vitae, 2005, 420 p. », Abstracta Iranica [En ligne], Volume 28 | 2007, document 268, mis en ligne le 18 septembre 2007, consulté le 25 septembre 2020. URL : http:// journals.openedition.org/abstractairanica/12582; DOI : https://doi.org/10.4000/abstractairanica. 12582

Ce document a été généré automatiquement le 25 septembre 2020.

Tous droits réservés 


\section{The Reflective Heart - Discovering Spiritual Intelligence in Ibn 'Arabî's Meccan Illuminations. Louisville, Fons Vitae, 2005, 420 p.}

\section{Pierre Lory}

Dans ce volume substantiel, J.M. a regroupé des textes d'études précédentes mais en les harmonisant et les réécrivant en sorte d'obtenir un ensemble harmonieux. Il y présente différents thèmes akbariens fondamentaux en cinq grandes parties: "Voyage", "Audition", "Vision», "Discernement ", « Retour». Chacun de ces chapitres est présenté avec autant de clarté que d'érudition (étayée par une imposante annotation renvoyant en particulier aux différents passages de l'œuvre océanique d'Ebn 'Arabī, par une bibliographie et un index), et comprend souvent de belles envolées (par ex. à propos de l'audition). Ils nous livrent autant de clés de lecture des plus utiles pour une œuvre souvent si abstruse et déroutante, sans jamais céder sur la profondeur et la rigueur des analyses.

\section{INDEX}

Thèmes : 7. Islam 
AUTEURS

PIERRE LORY

EPHE - Paris 